needs and resources for promoting mental health. This monograph is the fifth to be published in the series of reports prepared for the joint commission. The authors, who are non-medical, are experienced in the organization of welfare activities for large communities. They spent two years in collecting data about the relevant social resources throughout the country and making a more detailed field study of 15 counties which had characteristics typical of their respective regions.

The report contains much factual information about the various social services, It confirms, rather than reveals, the lack in many communities of adequate social provision for people with psychiatric troubles: it also confirms the suspicion that there is no satisfactory yardstick for determining what is adequate (as distinct from ideal) social provision for such people. The monograph is much larger, flabbier, and heavier than it would have been if written firmly and concisely.

\section{Course in Electroencephalography}

The International Federation of Societies for Electroencephalography and Clinical Neurophysiology announces that an advanced course in electroencephalography will be held in Marseilles from August 28 to September 2 1961. Application forms for those who wish to attend may be obtained from Dr. O. Magnus, St. Ursula Clinic, Wassenaar, Holland.

\section{International Congress of Neuroradiology}

The next international congress of neuroradiology (VI Symposium Neuroradiologicum) will be held in Rome from September 18 to 22, 1961, under the Presidency of Dr. Giovanni Ruggiero. All correspondence should be addressed to Dr. Enzo Valentino, General Secretary, VI Symposium Neuroradiologicum-CITUfficio Congressi, Piazza Colonna 193, Rome.

\section{Congress on Mental Retardation}

The second international congress on mental retardation will take place in Vienna from August 14 to 19, 1961. Further information may be obtained from the Secretary of the Congress, Universitatskinderklinik, Wien IX, Lazarettgasse 14, Austria.

\section{International Symposium of Stereoencephalotomy}

An international symposium on stereotaxic surgery will be held under the direction of Drs. E. A. Spiegel and Henry T. Wycis on October 11, 1961, at Philadelphia. Enquiries should be sent to Dr. Henry T. Wycis, 3401 N. Broad Street, Philadelphia 40, Pa., U.S.A.

\section{BOOKS RECEIVED}

(Review in a later issue is not precluded by notice here of books
recently received.)

Le Foie Alcoolique de L'Hépatite a la Cirrhose Alcoolique. By P. Etienne-Martin and Cl. Klepping. (Pp. 162; 7 figures and 10 tables. NF 20.-.) Paris: Masson \& Cie. 1960.
Nerve Endings in Normal and Pathologic Skin. By K. Winkelmann. (Pp. viii $+195 ; 42$ figures. 60s Oxford: Blackwell; Springfield, Illinois: Thomas. 1960

Child Guidance Centres [Wld Hlth Org. Monogf. Ser. No. 40.] By D. Buckle and S. Lebovici. (Pp. 13 20s.) Geneva: World Health Organization; Londo H.M.S.O. 1960.

Cerebral Palsy and Related Disorders: A Develop mental Approach to Dysfunction. By Eric Denhoff and Isabel Pick Robinault. (Pp. ix +421 ; illustrated. 93s London: McGraw-Hill. 1960.

Das Schädelhirntrauma: Leitfaden der Diagnostik ung Therapie. By M. Klinger; Foreword by R. Nisse (Pp. viii $+176 ; 19$ figures. DN 19.80.) Stuttgar? Thieme. 1961.

Markhaltige Faserverbindungen am Hirnstamm de् Katze. By S. Burgi and V. M. Buchner. (Pp. iv + 127? 49 figures. DM 39.60.) Berlin-Wilmersdorf: Springe? Verlag. 1960.

Anatomie des Menchen: Ein Lehrbuch für Studierend $\vec{w}$ und Ärtze. By H. Braus; Foreword by E. Elze. (P viii +832 ; 545 figures. DM 69.-.) Berlin-Wilmersdor Springer-Verlag. 1960.

Rorschachiana VII. 4. Internationaler Rorschach Kongress, Brüssel, 1-4 August, 1958. (Pp. 187; 14 figures, 9 tables. DM 23.80.) Berne: Hans Huber 1960.

Experimental Psychology. By Burton G. Andreas

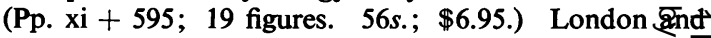
New York: John Wiley. 1960.

Mental Retardation in Infants and Children. 䣚y Abraham Levinson and John A. Bigler. (Pp. 308; 533 figures. 60s.; \$8.00.) Chicago: The Year BEoR. Publishers (London: Interscience Publishers). 1960.

Die Chirurgie des Nervus Facialis. By Adolf Miehlke with an Introduction by Prof. Paul Falk. (Pp. xii 208; 45 colour and 53 text figures. DM 98.-.) Munic and Berlin: Urban and Schwarzenberg. 1960.

Studies on Medical and Population Subjects No. 16 Area of Residence of Mental Hospital Patients. General Register Office. (Pp. iv +177 . 15s. 6d.) London? H.M.S.O. 1960.

Manuel de Psychiatrie. By Henri Ey, P. Bernard, an Ch. Brisset. (Pp. 1014; 31 figures. NF 100.-.) Paris? Masson \& Cie. 1960.

Fear and Depression: Their Causes and Self-Treatment? By Allan Worsley. (Pp. 84 + Foreword + Index 8s 6d.) London: George Allen \& Unwin. 1961.

The Central Nervous System and Behavior. Transaci tions of the Third Conference, February 21, 22, 23 an\& 24, 1960. Edited by Mary A. B. Brazier. (Pp. $475^{2}$ 201 figures. \$7.50.) New York: Josiah Macy, Jro Foundation. 1960.

Principles of General Neurophysiology Relating to Anaesthesia and Surgery. By Barry D. Wyke. (Pp. ix t 136; 26 figures. 21s.) London: Butterworths. 1960?

Structure and Function of the Cerebral Cortex. Prof ceedings of the Second International Meeting of Neurop biologists (Amsterdam, 1959). Edited by D. B. Tower and J. P. Schadé. (Pp. xi +448 ; illustrated. 85s.) London: D. Van Nostrand. 1960. 